\title{
Systematically Important Banks and Increased Capital Requirements in the Dodd-Frank Era
}

\author{
Lutz, Chandler
}

Document Version

Accepted author manuscript

Published in:

Economics Letters

DOI:

10.1016/j.econlet.2015.11.034

Publication date:

2016

License

CC BY-NC-ND

Citation for published version (APA):

Lutz, C. (2016). Systematically Important Banks and Increased Capital Requirements in the Dodd-Frank Era. Economics Letters, 138, 75-77. https://doi.org/10.1016/j.econlet.2015.11.034

Link to publication in CBS Research Portal

\section{General rights}

Copyright and moral rights for the publications made accessible in the public portal are retained by the authors and/or other copyright owners and it is a condition of accessing publications that users recognise and abide by the legal requirements associated with these rights.

\section{Take down policy}

If you believe that this document breaches copyright please contact us (research.lib@cbs.dk) providing details, and we will remove access to the work immediately and investigate your claim.

Download date: 26. Apr. 2023
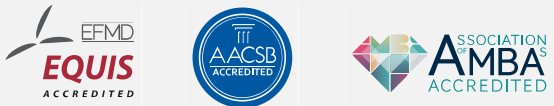


\title{
Systematically Important Banks and Increased Capital Requirements in the Dodd-Frank Era
}

\section{Chandler Lutz}

\author{
Journal article (Post print version)
}

This article was originally published in Economics Letters, Vol. 138, Nr. January,

२०१6, Pages. ७५-77. First published online 11 December २०1५.

DOl: 10.1016/j.econlet.2015.11.034

Uploaded to Research@CBS: Januar २०16

(1) 2016. This manuscript version is made available under the CC-BY-NC-ND 4.0 license http://creativecommons.org/licenses/by-nc-nd/4.0/ 


\title{
Systematically Important Banks and Increased Capital Requirements in the Dodd-Frank Era
}

\author{
Chandler Lutz* \\ Copenhagen Business School \\ Forthcoming, Economics Letters
}

November 25, 2015

\begin{abstract}
This paper analyzes the effects of new capital requirements for systematically important financial institutions proposed by the Federal Reserve on September 8, 2014. Results from an event study indicate this announcement led to lower abnormal initial stock returns for systemically important financial firms that then reverse and dissipate after three days. Further, findings suggest that the announcement of the proposed rule change had no impact on key interest series. Overall, the results are consistent with an initial overreaction and subsequent market correction to the announcement of the proposed regulation by equity market investors.
\end{abstract}

JEL Classification: G18, G28, G21;

Keywords: Systematic Risk, Capital Requirements, Financial Regulation, Dodd-Frank

*Department of Economics. Email: cl.eco@cbs.dk. Lutz would like to thank the Copenhagen Business School for funding and support. 
After the market close on September 8, 2014, the Federal Reserve proposed increased capital requirements for systematically important financial institutions using powers established by the 2010 Dodd-Frank Act! This paper analyzes the effects of this surprise announcement on the equity returns of systematically important financial institutions and key interest rate series ${ }^{2}$ Our findings imply that abnormal returns for the systematically important financial institutions initially fell after the announcement of the proposed rule changes. These effects then dissipated after three days; consistent with an initial overreaction and subsequent correction in equity markets. Further, the results indicate that the policy intervention had no effect on Treasury yields or corporate bond rates; suggesting that the announcement of the newly proposed capital requirements had no impact on key financial market interest rates.

\section{Data}

We consider the stock prices for all members of the S\&P500 Financials Index using data from Yahoo Finance $3^{3}$ Systematically important financial institutions are from the Financial Stability Board $\rrbracket^{4}$ We download equity market cap information from Bloomberg. Lastly, the 2-, 5-, 10-, 20-, and 30-year zero-coupon Treasury yields and the Moody's Aaa and Baa seasoned corporate bond yields are also from Bloomberg.

\section{Event Study and Main Results}

To assess the effects of the announcement of the proposed increase in capital requirements, we employ an event study framework. The surprise announcement and hence the exogenous shock is the proposed capital requirements disclosed in Congressional Testimony by Fed Governor Daniel Tarullo. While the Fed Governor Tarullo did not explicitly state the precise capital levels that would be implemented, he did signal that he Fed would pursue

\footnotetext{
${ }^{1}$ See "The Fed Wants Capital, Not Punishment." Bloomberg News. September 9, 2014. Available at http://www.bloombergview.com/articles/2014-09-09/the-fed-wants-capital-not-punishment; and "Fed to Hit Biggest U.S. Banks With Tougher Capital Surcharge." The Wall Street Journal. September 9, 2014. Available at http://online.wsj.com/articles/feds-tarullo-says-fed-board-will-unveil-systemicallyimportant-financial-institution-surcharge-rule-soon-1410211114. For an overview of the Dodd-Frank Act see Acharya et al. (2010).

${ }^{2}$ The list of systematically important financial institutions is constructed by the Financial Stability Board. See http://www.financialstabilityboard.org/publications/r_131111.htm.

${ }^{3}$ The S\&P500 Financials Index contains 83 firms in total.

${ }^{4}$ We include systematically important financial institutions that are traded on US exchanges. The firms include JP Morgan (JPM), Citigroup (C), Goldman Sachs (GS), Morgan Stanley (MS), The Bank of New York Mellon Corp (BK), State Street (STT), and Wells Fargo (WFC).
} 
more stringent capital requirements $5^{5}$ The methodology and results are discussed for the equity returns on the systematically important financial firms and for the key interest rate series in turn.

\subsection{Systematically Important Financial Institutions and Stock Returns}

Our event study methodology follows Acemoglu et al. (2013) and Campbell, Lo, and MacKinlay (1997) ${ }^{6}$ The proposed rule changes were announced after the market closed on September 8, 2014. Thus, the timing of our event study is as follows: We let Period 0 be the time from the market close on September 8, 2014 to the market opening on September 9, 2014; then Period 1 is the time from the market opening on September 9 to the market close on September 9; and Period 2 is defined as the time from the market close on September 9 to the market close on September 10. From there, we follow Acemoglu et al. (2013) and calculate abnormal returns and cumulative abnormal for all stocks that make up the S\&P500 Financials Index.7 With the abnormal and cumulative abnormal returns in hand, we examine the mean returns for the systematically important and non-important financial firms and the corresponding difference in the mean returns between these two groups. A two-sided t-test is used to evaluate the null hypothesis that the difference in mean returns between these two groups is equal to zero. Also, we assess the effects of the announcement on equity returns for the systematically important

\footnotetext{
${ }^{5}$ As noted by a referee, the effects of the proposed capital regulations may be related to the increases in bank capital requirements or to an increase in uncertainty associated with the policy change as the exact level of capital increases was not explicitly stated. To examine the effects of the policy on uncertainty, we download from Datastream the Chicago Board Options Exchange (CBOE) implied volatility indices for the S\&P500, the NASDAQ 100, the Dow Jones Industrial Average, the Russell 2000, Amazon, Apple, Goldman Sachs, Google, and IBM (all equity implied volatility indices that are available). Following Bloom (2009) and Lutz (2014), the implied volatility indices can be interpreted as measures of uncertainty. We find that the average percentage increase from the close on September 8 to the close on September 9, 2014 was 3.54 percent with a standard deviation of 5.55 percentage points across all of the considered VIX indices. The increase in the VIX for Goldman Sachs, the only systematically important financial institution for which an implied volatility measure is calculated, was 3.94 percent. In a statistical test, we fail to reject the null hypothesis that the increase in uncertainty for Goldman Sachs was different from the mean. If uncertainty increased due to this change in regulatory policy, we would expect there to be a related increase in uncertainty for Goldman Sachs returns. Yet we do not find any such increase in the Goldman Sachs VIX. Hence, our results are consistent with investors reacting to increased capital standards, not an increase in uncertainty regarding future direction of policy.

${ }^{6}$ For other recent event studies see Krishnamurthy and Vissing-Jorgensen (2011) and Glick and Leduc (2013)

${ }^{7}$ As in Acemoglu et al. (2013), abnormal returns (AR) are calculated as $A R_{i t}=R_{i t}-\left[\hat{\alpha}_{i}+\hat{\beta}_{i} R_{m t}\right]$; where $R_{i t}$ is the return for firm $i$ at time $t, R_{m t}$ is the market return measured by the S\&P500, and $\hat{\alpha}_{i}$ and $\hat{\beta}_{i}$ are estimated from the equation $R_{i t}=\alpha_{i}+\beta_{i} R_{m t}+\varepsilon_{i t}$ over a 250-day window 30 days prior to Period 0 . Then cumulative abnormal returns are computed using the following formula: $C A R[0, n]_{i}=\sum_{t=0}^{n} A R_{i n}$. Note that an assumption with this approach is that the CAPM model holds with when calculating abnormal returns.
} 
financial firms using a regression model; this approach allows us to control firm-level characteristics including firm size..$^{8}$ The results are reported in table $\left.1\right|^{9}$ First, the results are qualitatively similar across the OLS and the difference-in-means analysis; indicating that controlling for firm size does not have a meaningful impact on our results. Next, the findings indicate that in response to the announcement of the proposed capital increases, the returns on systematically important firms fell by approximately 0.51 percent during Period 0 and by 0.74 percent after both Periods 0 and 1 relative to systematically non-important financial firms. ${ }^{10}$ Then the effect of the announcement dissipates after Period 2 as the OLS estimate when the cumulative abnormal returns serve as the dependent variable becomes insignificant. Overall, these results are consistent with an initial overreaction and subsequent market correction in the relative response of returns on systematically important financial firms to the announcement of the newly proposed capital requirements on September 8, 2014.

\subsection{Increased Capital Requirements and Key Financial Market Interest Rates}

Next, we examine the impact of the increased capital requirements on key financial market interest rates including zero-coupon Treasury yields and Moody's corporate bond yields ${ }^{11}$ Here, we aim to assess the hypothesis considered by the Bank of International Settlements that increased capital requirements would induce banks to reduce lending and thus widen interest rate spreads ${ }^{12}$ Changes and cumulative changes in the interest rate series are calculated for Periods 0,1 , and 2 and statistical significance is assessed via a bootstrapping algorithm ${ }^{13}$ Overall, this approach mirrors that used above for equity returns. The results, which are presented in table 2 , indicate that the announcement of

\footnotetext{
${ }^{8}$ Specifically, we estimate the following regression model: $Z_{i}=\beta_{0}+\beta_{1} \operatorname{Important}_{i}+\beta_{2} \log \left(\operatorname{size}_{i}\right)+\varepsilon_{i}$, where $Z_{i}$ is the abnormal or cumulative abnormal return for firm $i$ for the relevant period, Important is a dummy variable for systematically important financial firms, and $s i z e_{i}$ is the market cap for firm $i$. p-values are then calculated using a bootstrapping algorithm.

${ }^{9}$ In the table, p-values are in parentheses.

${ }^{10}$ We obtain these point estimates using the OLS estimates.

${ }^{11}$ As the Treasury rates and corporate bond yields are only available at the end of the trading day, our timing for the event study in this section is as follows: Periods 0, 1, and 2 represent the market close on September 9, September 10, and September 11 for the year 2014, respectively.

12 "How have banks adjusted to higher capital requirements?" BIS Quarterly Review. September 2013.

${ }^{13}$ We calculate the daily first difference in yields (Diff) as follows: Dif $f_{i t}=Y_{i t}-Y_{i, t-1}$, where $Y_{i t}$ is the yield for interest rate series $i$ at time $t$. Cumulative differences (CumDiff), the total change in the interest rate series, is calculated as CumDiff $[0, n]_{i}=\sum_{t=0}^{n} \operatorname{Diff}_{\text {in }}$. 95-percent bootstrapped confidence intervals are computed using one year of data 30 days prior to Period 0 using the relevant window for Diff and CumDiff, respectively.
} 
the proposed capital increases for systematically important financial institutions did not have an economically meaningful impact on key financial market and economic interest rates 14

\section{Conclusion}

Using an event-study approach, we assess the impact of recently proposed capital increases for systematically important financial institutions on the stock returns for these institutions as well as for important financial market and economic interest rates. Our results indicate that the announcement of the proposed regulation led to an initial decrease and subsequent reversal in the relative returns of systematically important financial firms. These results are consistent with an initial overreaction and eventual correction in the equity returns of major financial firms. Further, findings suggest that the proposal of the increased capital standards for large financial institutions had no impact on economic and financial market interest rates.

\footnotetext{
${ }^{14}$ All of the Differences and Cumulative Differences in the interest rate series lie inside their respective 95-percent bootstrapped confidence intervals; suggesting that the proposed regulation had little impact on key interest rates.
} 


\section{References}

[1] D. Acemoglu, S. Johnson, A. Kermani, J. Kwak, and T. Mitton. The value of connections in turbulent times: evidence from the united states. 2013.

[2] V. V. Acharya, T. F. Cooley, M. P. Richardson, I. Walter, et al. Regulating Wall Street: The Dodd-Frank Act and the new architecture of global finance, volume 608. John Wiley \& Sons, 2010.

[3] N. Bloom. The impact of uncertainty shocks. Econometrica, 77(3):623-685, 2009.

[4] J. Y. Campbell, A. W. Lo, and A. C. MacKinlay. The econometrics of financial markets. 1997.

[5] R. Glick and S. Leduc. The effects of unconventional and conventional us monetary policy on the dollar. Manuscript, Federal Reserve Bank of San Francisco, 2013.

[6] A. Krishnamurthy and A. Vissing-Jorgensen. The effects of quantitative easing on interest rates: Channels and implications for policy. Brookings Papers on Economic Activity, pages 215-287, 2011.

[7] C. Lutz. Unconventional monetary policy and uncertainty. Working paper, 2014. 
A Tables 


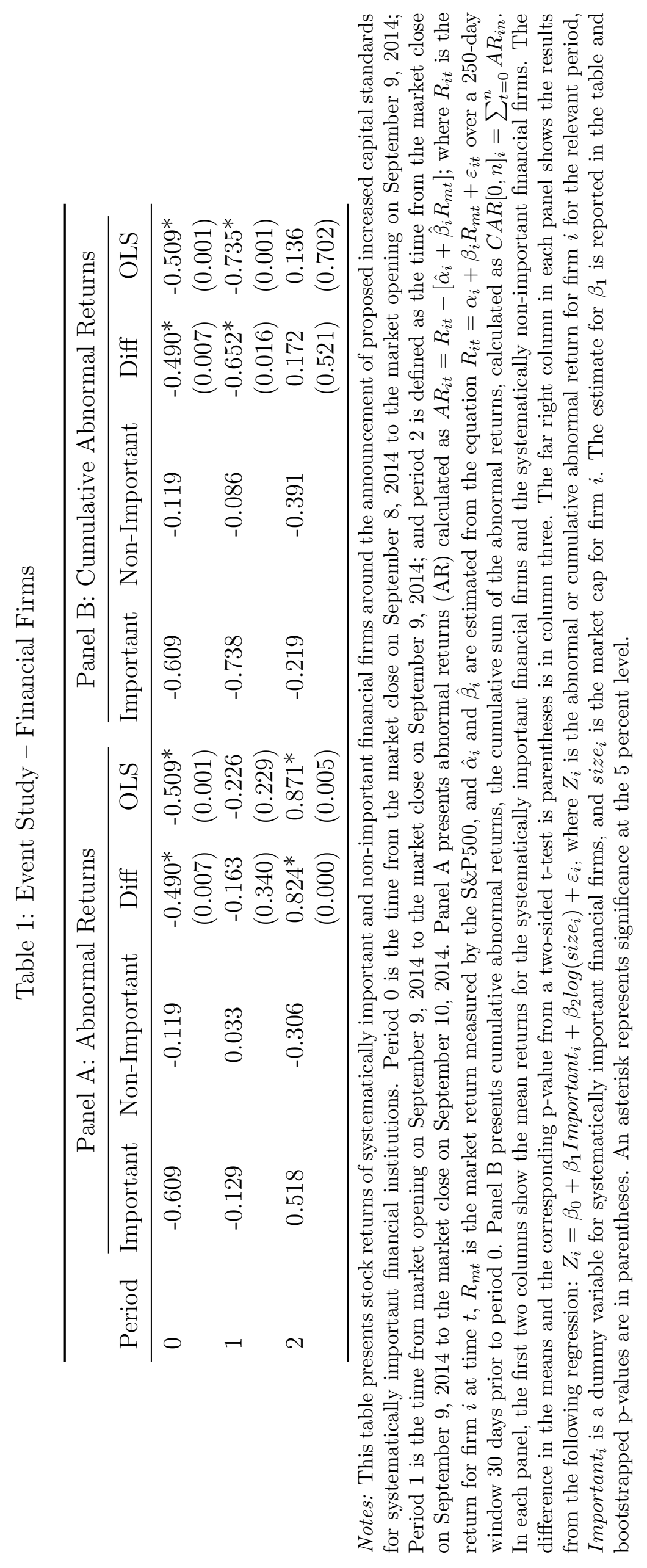




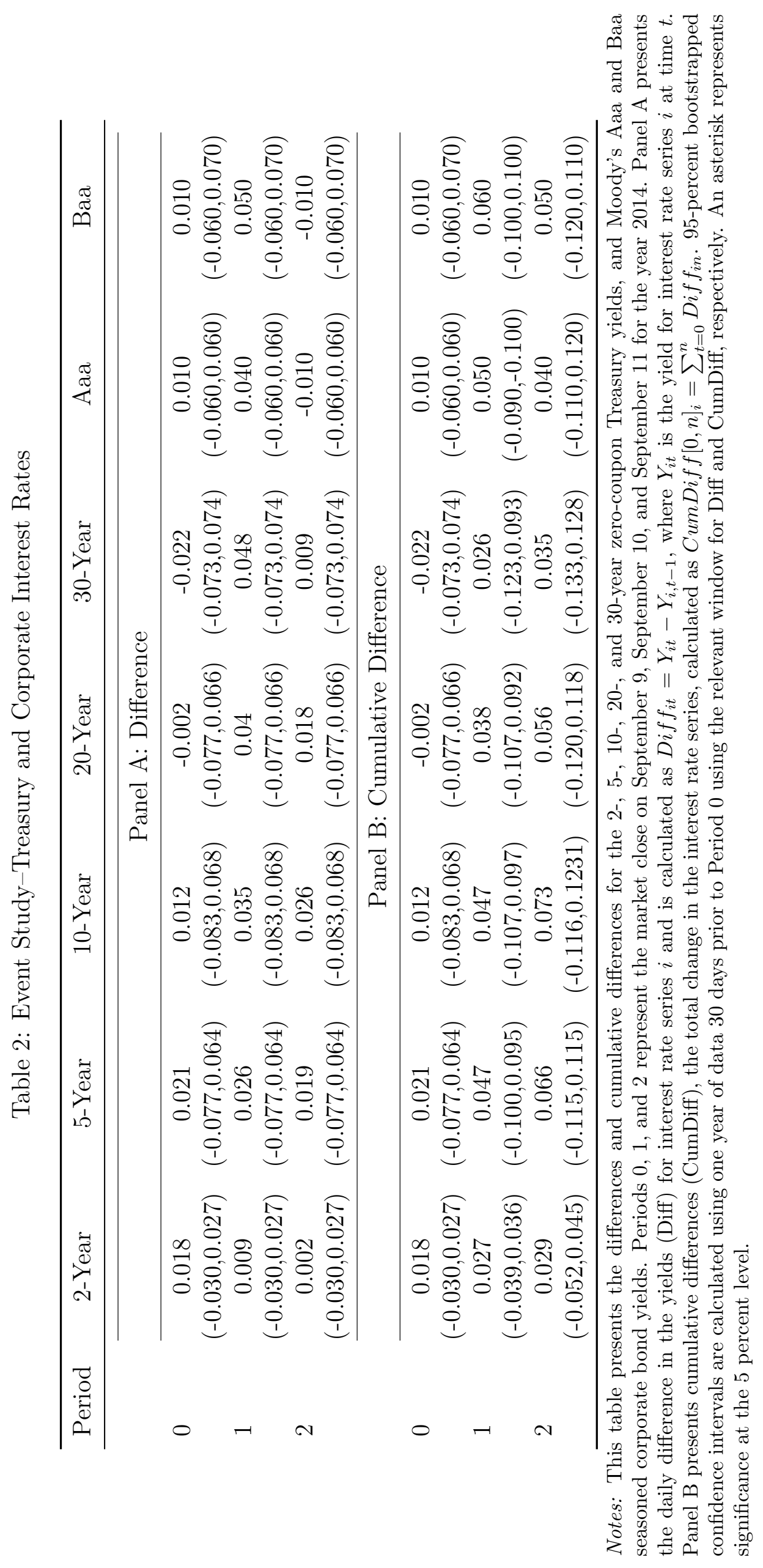

